\title{
LIGHT-DARK CYCLES IN OPAL-RICH SEDIMENTS NEAR THE PLIO-PLEISTOCENE BOUNDARY, DSDP SITE 532, WALVIS RIDGE CONTINENTAL TERRACE
}

\author{
LISELOTTE DIESTER-HAASS ${ }^{1}$, PHILIP A. MEYERS ${ }^{2}$ and PETER ROTHE ${ }^{1}$ \\ ${ }^{1}$ Institute of Geography and Geology, University of Mannheim, D-6800 Mannheim 1 (F.R.G.) \\ ${ }^{2}$ Oceanography Program, Department of Atmospheric and Oceanic Science, and Great Lakes and \\ Marine Waters Center, University of Michigan, Ann Arbor, MI 481092143 (U.S.A.)
}

(Received June 17, 1985; revised and accepted March 31, 1986)

\begin{abstract}
Diester-Haass, L., Meyers, P.A. and Rothe, P., 1986. Light-dark cycles in opal-rich sediments near the Plio-Pleistocene boundary, DSDP Site 532, Walvis Ridge continental terrace. Mar. Geol., 73: $1-23$.

Samples taken at $10 \mathrm{~cm}$ intervals from DSDP Core 532B-17 contain variations in carbonate, opal, organic carbon, and terrigenous components that correlate with light-dark cycles in sediment color. The core site, at $1300 \mathrm{~m}$ water depth, is well above the CCD, yet the color variations appear to result largely from cyclical fuctuations in carbonate dissolution, which was greater during glacial periods. Higher concentrations of organic carbon and of terrigenous sediment components correlate with enhanced carbonate dissolution, but opal concentrations inversely correlate and suggest that biological productivity at this site diminished during glacial periods. A complicated glacial-interglacial picture emerges from the data. In interglacial times, upwelling associated with the Benguela Current produced abundant opaline material, organic matter was fairly well preserved, and carbonate was only moderately dissolved. In glacial times, the upwelling core shifted as sea level fell and winds intensified. Productivity in the waters over Site 532 decreased, but lateral supply of oxidizable organic matter enhanced carbonate dissolution, giving rise to light-dark cycles in these sediments.
\end{abstract}

\section{INTRODUCTION}

Sediments deposited on the landward terrace of the Walvis Ridge offshore of Southwest Africa record the history of upwelling and enhanced biological productivity associated with the Benguela Current. Several locations under this cold, northward flowing current have been sampled as part of the Deep Sea Drilling Project (DSDP). Based upon concentration patterns of organic carbon, diatom species abundances, and nutrient incorporation in sediments obtained at Site 362 by rotary drilling during DSDP Leg 40 , Siesser (1980) concludes that development of this current and the onset of upwelling began about $10 \mathrm{~m} . \mathrm{y}$. ago in late Miocene times.

Sediments from nearby Site 532 (Fig.1) were obtained during DSDP Leg 75 by hydraulic piston coring and, therefore, provide a less-disturbed record than 

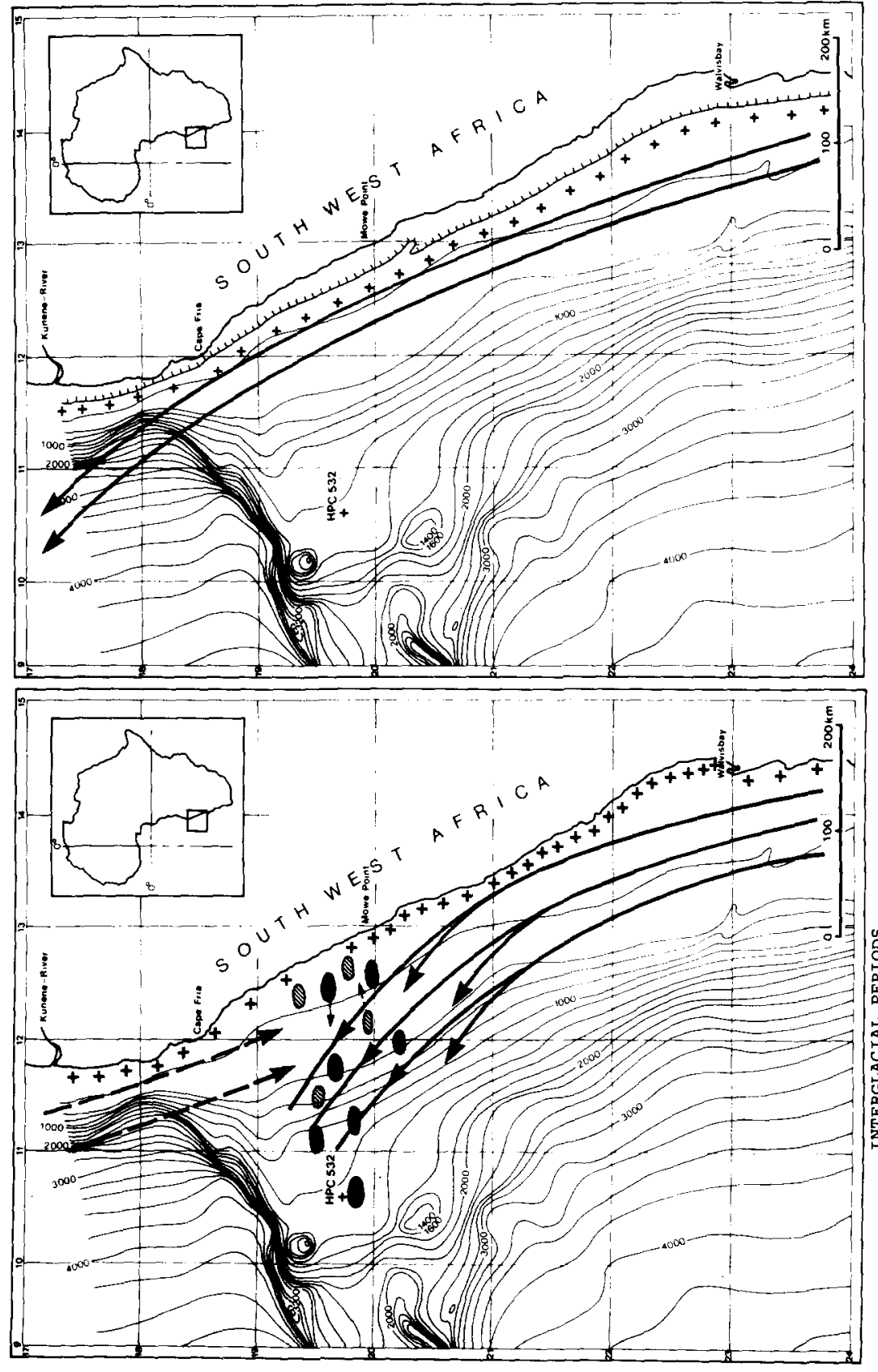

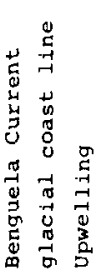


contained in sediments from Site 362. Dean et al. (1984) summarized studies of Site 532 sediments and noted two important features not evident from the Site 362 data. First, biological productivity over Site 532 evidently maximized during late Pliocene and early Pleistocene times. Second, cyclic variations in color and in concentrations of organic carbon, calcium carbonate, and clay occur throughout the sedimentary record with average periodicities of 30-60 thousands of years. Diatom compositions lead Sancetta (1984) to suggest that fluctuation in the intensity and location of the Benguela Current might account for the cyclic variations. Such fluctuations may result from glacialinterglacial sea-level changes (Dean et al., 1984). This latter possibility has been expanded upon by Gardner et al. (1984), who conclude that cycles in neither carbonate dissolution nor in local productivity are the principal causes of the variations in sediment color and composition. They instead propose that cyclic changes in global climate resulted in fluctuations in the local influx of land-derived clastic components to the Walvis Ridge sediments, diluting to a greater or lesser degree the largely biogenic record.

To investigate further the nature of the cyclic variations found at Site 532, we conducted detailed studies of samples obtained at $10 \mathrm{~cm}$ intervals through three such cycles in one core of opal-rich sediment deposited within the productivity maximum near the Plio-Pleistocene boundary in Hole 532B. The results of our sedimentological studies are reported here. Organic geochemical details are presented separately (Meyers et al., in prep.), and comparisons with cyclic variations from other parts of the Walvis Ridge record are given in Diester-Haass (1985).

MATERIAL AND METHODS

\section{Samples}

We investigated 37 samples collected at approximately $10 \mathrm{~cm}$ intervals from Core 17, located between 69 and $74 \mathrm{~m}$ subbottom in Hole 532B. The sediments consist of diatom-rich biogenic marls and oozes made up of varying contributions of nannofossils and foraminifers and contain small amounts of clay. Deposition occurred during the early Pleistocene and late Pliocene at an average rate of $50 \mathrm{~m} \mathrm{m.y.} .^{-1}$ (Hay, Sibuet et al., 1984). Throughout the sediments, light-dark color cycles up to a few meters in core length are found. Light-colored regions contain less clay, organic matter, and pyrite and have more carbonate than do the darker layers. Bioturbation is commonly extensive throughout this unit and has smeared the light-dark banding, yet the alternations remain obvious.

The $375 \mathrm{~cm}$ portion of Core 532B-17 studied, contained three light-dark cycles. If the mean linear accumulation rate of $5 \mathrm{~cm} 1000 \mathrm{yrs}^{-1}$ is used, then these three cycles total 75,000 years and average about 25,000 years apiece. The average spacing of our 34 samples is 2200 years on this basis. 
Analysis

The coarse fractions of sediment were analyzed after being dried, weighed, and separated by washing through 40 and $63 \mu \mathrm{m}$ sieves. The $<40 \mu \mathrm{m}$ fraction was dried, and the $<2 \mu \mathrm{m}$ fraction was used for the clay-mineral analysis. The residue $>40 \mu \mathrm{m}$ was dried and weighed. The sediment coarser than $63 \mu \mathrm{m}$ was sieved into five subfractions $(63-125,125-250,250-500,500-1000,>1000 \mu \mathrm{m})$ and the weight of each fraction was determined. In each fraction, including the 40-63 $\mu \mathrm{m}$ fraction, about 800 grains were counted (if present) and about 25 grain types were distinguished (various benthonic organisms, planktonic foraminifera (whole tests and fragments), radiolaria, diatoms, terrigenous matter, authigenous components, fecal pellets, plant debris, etc.). The percentage composition of each fraction and of the total sand $(>63 \mu \mathrm{m})$ fraction was calculated from these data.

The clay minerals were analyzed after separating the $<2 \mu \mathrm{m}$ fraction in Atterberg settling tubes. Carbonate was dissolved with acetic acid, and the residues were pipetted onto glass slides. To avoid selective settling of smectite and to obtain maximum parallel texture, the samples were smeared after accumulation of sufficient material from the pipette. Samples were then run in a Philips APD IO diffractometer with Ni-filtered $\mathrm{Cu} \mathrm{K}$ radiation. The tube was operated at $40 \mathrm{kV}$ and $30 \mathrm{MA}$. Scanning speed was normally $1^{\circ} 2 \phi \mathrm{min}^{-1}$, except in a special run to distinguish the kaolinite/chlorite peaks between 24 and $25.5^{\circ}$ when it was $1 / 4^{\circ} 2 \phi \mathrm{min}^{-1}$. Glycolated samples were run under the same conditions. Because the clay-mineral spectrum turned to be very uniform throughout the entire core, additional treatment was only applied on selected samples; these were heated to $350^{\circ}$ and $550^{\circ} \mathrm{C}$, respectively. The basal reflection of montmorillonite shifted, after glycolation, to only about $16 \mathrm{~A}$, but after heating the mineral clearly behaved like montmorillonite. We found similar swelling behaviour of montmorillonites also from Tertiary limestone--marl sequences (Klupsch and Rothe, in prep.). Peak areas of clay minerals were measured with a planimeter and weighted peak areas were calculated using the factors of Biscaye (1964). Quartz was similarly determined by measuring the areas of the 101 peaks of powdered bulk samples.

Bulk samples were freeze-dried for determination of their total carbon contents with a Hewlett-Packard 185B CHN Analyzer. Residual carbon was measured after $\mathrm{HCl}$ dissolution of carbonates and was considered to represent the total organic carbon content. Percent calcium carbonate was calculated from the difference between initial and residual carbon contents. Organic matter atomic $\mathrm{C} / \mathrm{N}$ ratios were determined from residual carbon values. Percent organic carbon contents of the samples were calculated on a dryweight basis for the original, carbonate-containing sediment.

Oxygen isotope ratios of the benthic foraminifer Uvigerina sp. from selected samples were kindly determined by N.J. Shackleton of Cambridge University. 
The $\mathrm{CaCO}_{3}$ content varies between 18 and $59 \%$ by weight and shows maximum values in light zones and minimum values in dark units (Fig.2a). The organic carbon content of the bulk sediment changes between minima of about $1.5 \%$ in light units and maxima above $4 \%$ in dark units (Fig.2b). Oxygen isotope ratios have been determined only in Section 532B-17-2. Lowest ratios $(3.5 \%)$ are in the light unit, and a maximum of $4.5 \%$ is in the dark unit. The transition from low to high $\delta^{18} \mathrm{O}$ values is very rapid, within $12 \mathrm{~cm}$ (Fig.2c), which may correspond to about 2400 years.

The sand fraction (>63 $\mu \mathrm{m}: 1-4 \%$ ) and the coarse silt fraction $(40-63 \mu \mathrm{m}$ : $0.5-2 \%$ ) are minor components of the total sediment. These coarse fractions nonetheless contain important information about the bulk sediment. For example, the amount of carbonate dissolution is indicated by the planktonic foraminifera component of the coarse fractions. Biogenic opal in the coarse fraction is only a small portion of the total opal, yet these coarse components accurately profile the total amount under upwelling regimes (Diester-Haass et al., 1973; Diester-Haass, 1977; Thiede et al., 1982). The composition of the sand fraction (Fig.2d) is characterized by three main components: radiolaria, planktonic foraminifera and benthos. Sand-sized diatoms occur in one light unit (532B-17-1, 90-140 cm). The percentages of these components show strong variations, with high radiolarian, low planktonic foraminiferal and high benthos abundances in dark units and low radiolarian, high planktonic foraminiferal and low benthos abundances in light units (Fig.2d).

Within the group of planktonic foraminifera, whole tests and fragments have been counted separately to obtain information on the degree of carbonate dissolution (Thunell, 1976). Fragmentation values are lower in the light than in the dark units (Fig.2e), except in the upper portion of Core 532B-17 where no trend is found. The ratio of benthonic to planktonic foraminifera (Fig.2f) is lower in light units than in dark ones and hence generally parallels the fragmentation curve of planktonic foraminifera.

Figure 3 summarizes indicators of variations in fertility. In Fig.3a the measured organic carbon value has been plotted and compared to a calculated organic carbon percentage. The calculated value gives the variations in organic matter content that should exist if only dissolution of $\mathrm{CaCO}_{3}$ were responsible for varying organic matter contents. Sample 532B-17-1, 75-80 cm, having the highest $\mathrm{CaCO}_{3}$ content, has been assumed to represent the "pelagic rain" (Dean et al., 1981). The organic carbon content of $1.5 \%$ in this sample is assumed to be the "normal value". For all other samples the organic carbon percentages have been calculated by comparing the loss in $\mathrm{CaCO}_{3}$ compared to Sample 532B-17-1, 75-80 cm. The ratio of the measured versus the calculated organic carbon content $(\mathrm{Cm} / \mathrm{Cc})$ (Fig. $3 \mathrm{~b})$ gives the factor by which the measured organic carbon content is higher than it would be if it were controlled only by dissolution. In the light units the factor is about 1 (Table 1), meaning that measured and calculated organic matter percentages are very 

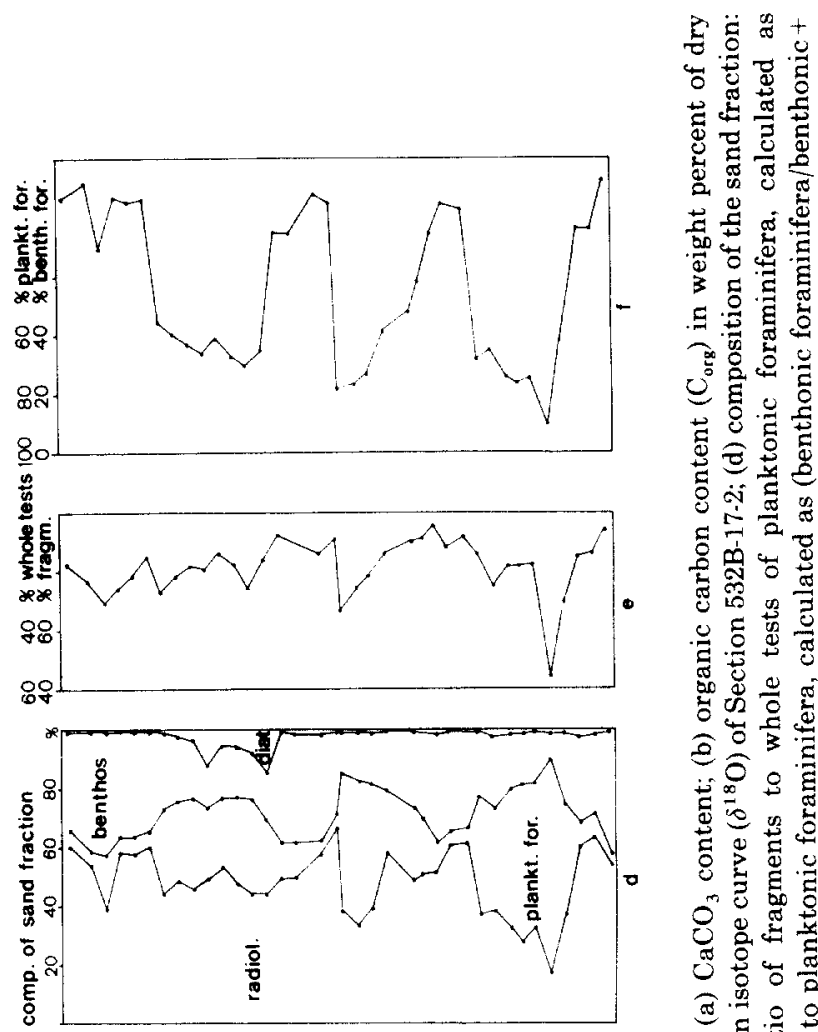

8 i $\frac{\pi}{5}$

हิ

○ 5 क

记罗要

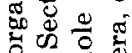

응

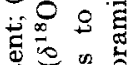

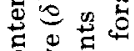

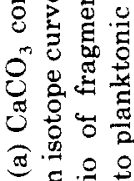

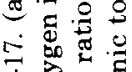

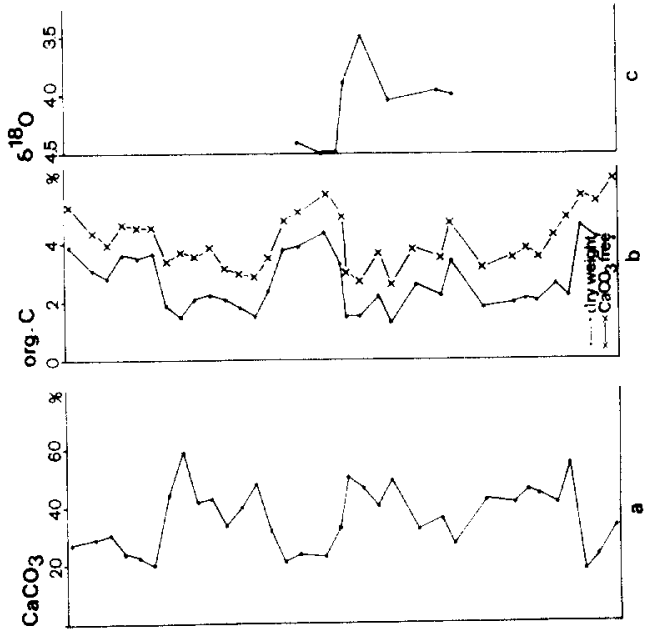

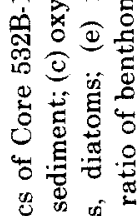

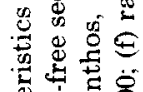

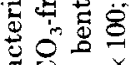

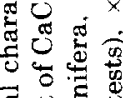

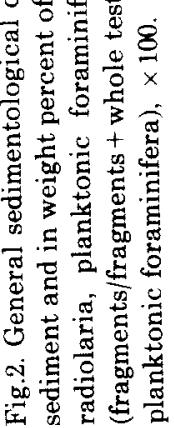




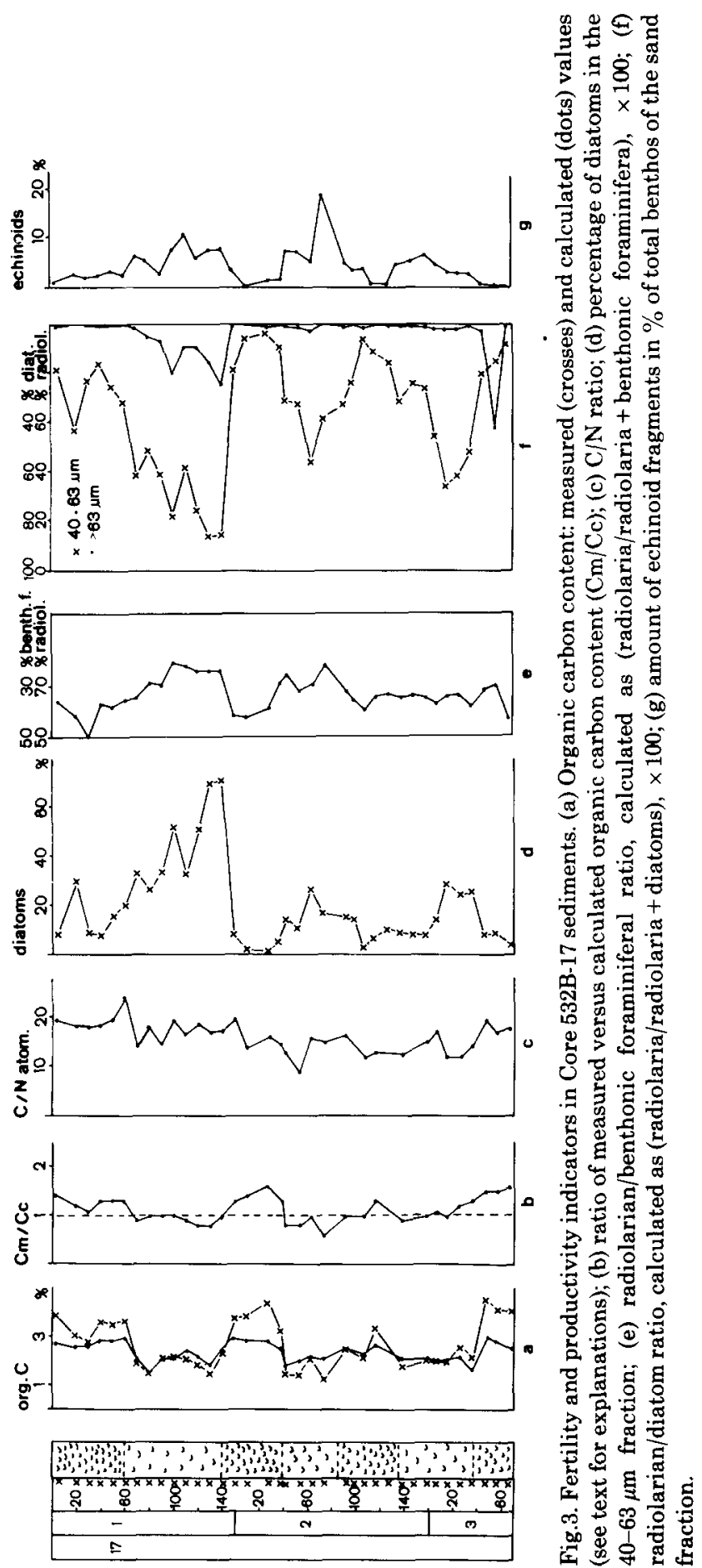




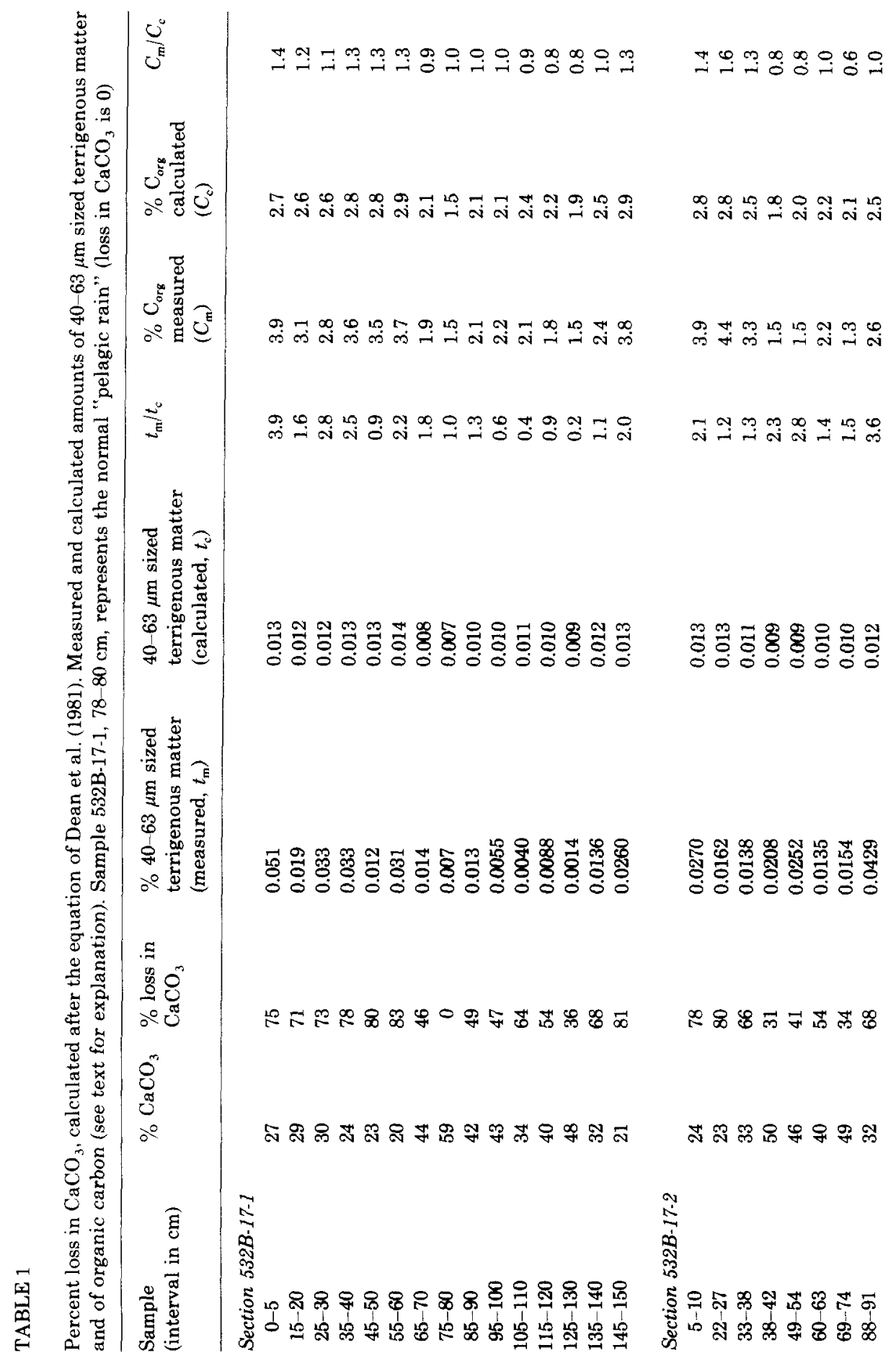




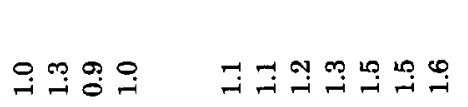

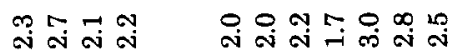

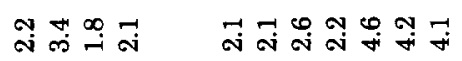

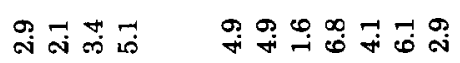

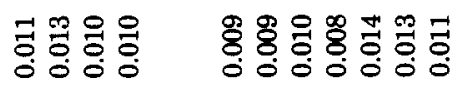

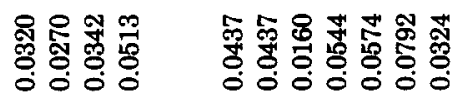

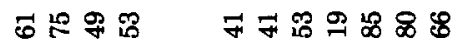

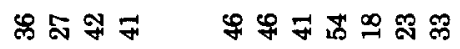

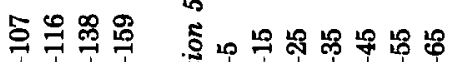

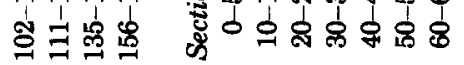


close and controlled only by dissolution of calcium carbonate. In dark units, however, the factor increases up to 1.5, suggesting that more organic matter is incorporated in the sediments during deposition of the dark units. Organic matter $\mathrm{C} / \mathrm{N}$ ratios vary between 8 and 24 and are not related to dark - light cycles (Fig.3c).

Abundance of opaline skeletons of diatoms is an important indicator of surface water fertility. In the coarse fractions $(>40 \mu \mathrm{m})$ investigated here, they are represented only by the biggest specimens. The more common diameter of diatoms is $<40 \mu \mathrm{m}$, hence in the sand $(>63 \mu \mathrm{m})$ fraction they are rare (Fig.2d) whereas in the $40-63 \mu \mathrm{m}$ fraction they form up to $70 \%$. Maxima are in the light units; minima in the dark ones (Fig.3d). The opaline skeletons of radiolaria form $17-65 \%$ of the sand fraction (Fig. $2 \mathrm{~d}$ ). Because these values can vary as a result of the degree of preservation of planktonic foraminiferal tests, the ratio of radiolaria versus benthonic foraminifera (which are much less subject to dissolution) has been used. These ratios (Fig.3e) show highest values (i.e., highest radiolarian amounts compared to benthonic foraminifera) in the light units and lowest values in the dark units. The radiolarian/diatom ratio (Fig.3f) shows strong variations with higher amounts of diatoms relative to radiolaria in the light units and lower proportions in the dark layers.

Benthos make up $15-50 \%$ of the sand fraction. These organisms consist mainly of benthonic foraminifera $(80-99 \%)$. Sponges, caecidae (gastropods), very rare ostracods, and echinoids form the remainder. Echinoderm spicules show variations related to dark/light units, with highest amounts (up to $10-18 \%$ of the total benthos) in the light units (Fig. $3 \mathrm{~g}$ ).

The terrigenous components of marine sediments can reflect the climatic history on the continents. In Fig.4a, the percentage of terrigenous matter (mainly quartz, some mica) of the $40-63 \mu \mathrm{m}$ fraction is higher in dark units than in light ones. In Fig. $4 \mathrm{~b}$, the $40-63 \mu \mathrm{m}$ sized terrigenous matter has been shown as both the measured and a calculated percent of the total sediment. Based again on Sample 532B-17-1, 75-80 cm as representing the "pelagic rain" of Dean et al. (1981) the content in 40-63 $\mu \mathrm{m}$ sized terrigenous matter of this sample was assumed to be the "normal" value. By calculating the loss in $\mathrm{CaCO}_{3}$ in each sample, the $40-63 \mu \mathrm{m}$ sized terrigenous matter content has been calculated (Table 1). In the light units the measured and the calculated terrigenous matter contents are similar, except for the upper part of the lowest light unit, whereas in the dark units the calculated amount is considerably larger. The increase of measured versus calculated $40-63 \mu \mathrm{m}$ sized terrigenous matter (Fig.4c) shows factors up to $2-3$ in the dark units of the upper part and up to 6 in the dark units of the lower part.

The mineralogical composition of the $<2 \mu \mathrm{m}$ fraction (Fig.4d) is uniform throughout both the dark and the light layers. The small variations are within the limit of analytical error. Illite peaks are narrow, indicative of a detrital origin, and chlorite is present as a minor component, barely above the detection limit. 

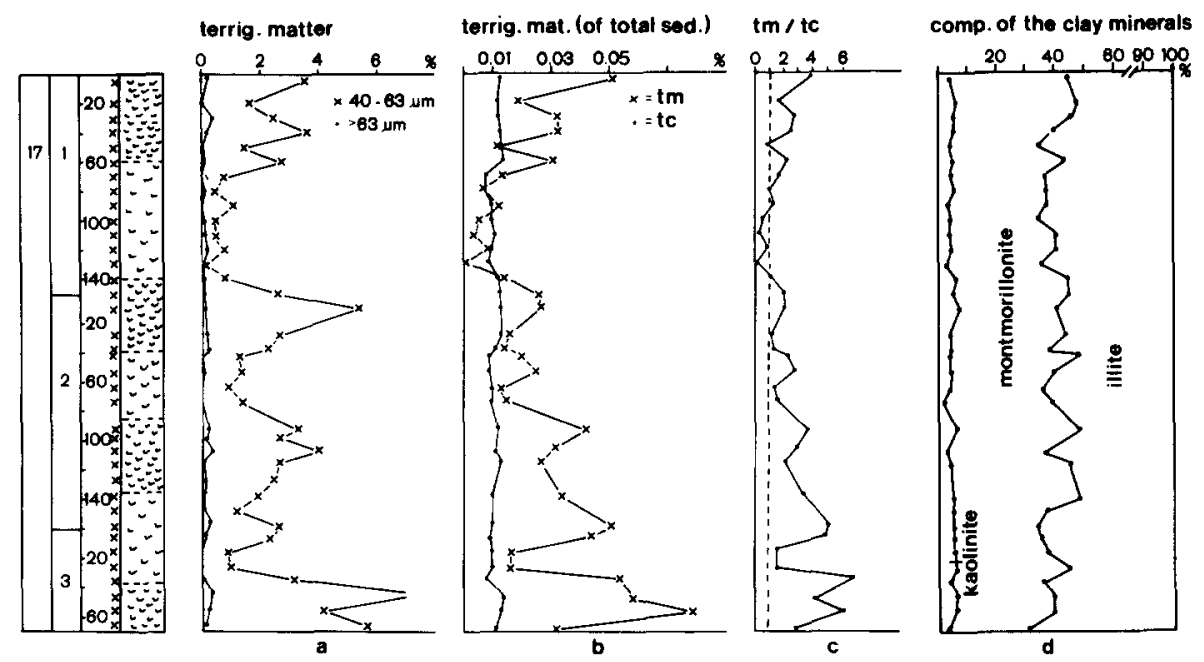

Fig.4. Terrigenous sediment components in Core 532B-17. (a) Amount of terrigenous matter in percent of the $40-63 \mu \mathrm{m}$ fraction; (b) amount of $40-63 \mu \mathrm{m}$ sized terrigenous matter in percent of total sediment. Measured values (crosses) $=t_{\mathrm{m}}$ and calculated values (dots) $=t_{\mathrm{c}}$ (see text for explanation); (c) ratio of measured $\left(t_{\mathrm{m}}\right)$ versus calculated $\left(t_{\mathrm{c}}\right)$ amount of $40-63 \mu \mathrm{m}$ sized terrigenous matter in total sediment; (d) composition of the clay minerals.

\section{DISCUSSION}

The light-dark color cycles in Core 532B-17 are accompanied by cyclic variations in nearly all the sedimentological parameters we investigated. We will discuss these results in terms of (1) carbonate dissolution as a reason for light-dark cycles, (2) fluctuations in marine fertility and productivity, and (3) glacial-interglacial climatic changes.

\section{Carbonate dissolution}

The $\mathrm{CaCO}_{3}$ contents show several variations related to the color changes. Concentration is inversely related to organic carbon contents with a good negative correlation $(r=-0.87)$. In comparison, Gardner et al. (1984) report a correlation coefficient of only -0.62 for $\mathrm{CaCO}_{3}$ and organic matter for the entire $292 \mathrm{~m}$ depth of Site 532. In section 532B-17-2, $\delta^{18} \mathrm{O}$ values are lower in light-colored intervals, reflecting an interglacial period, than in dark intervals, which probably record glacial periods.

Three processes can individually or in combination produce the varying $\mathrm{CaCO}_{3}$ content we find in these sediments: (1) varying dissolution of calcium carbonate; (2) varying production of calcium carbonate; and (3) varying dilution of calcium carbonate by terrigenous matter and opal. 


\section{Varying dissolution of calcium carbonate}

With increasing dissolution of $\mathrm{CaCO}_{3}$, shells of planktonic foraminifera become increasingly fragile and more broken; thus, the number of fragments increases compared to the number of whole tests (Thunell, 1976; Berger et al., 1982). The fragmentation curve (Fig.2e) parallels the $\mathrm{CaCO}_{3}$ curve: highest $\mathrm{CaCO}_{3}$ contents are correlated to lowest fragmentation values and vice versa.

As $\mathrm{CaCO}_{3}$ dissolves in sediments, planktonic foraminifera are preferentially lost, whereas benthonics are relatively enriched, because they are more robust and thus less susceptible to $\mathrm{CaCO}_{3}$ dissolution (Thunell, 1976; Berger et al., 1982). Hence, the ratio of benthonic to planktonic foraminifera can also be an indicator of calcium-carbonate dissolution if lateral supply of benthos from shallower water areas can be excluded. Investigation of five test samples from low carbonate content layers by B. Zobel (Hannover) from Site 532 revealed no shallow-water foraminifera, and lateral supply is therefore unlikely. Debris of other benthonic organisms, such as molluscs, bryozoans, etc., which normally indicate shallow-water origins, have also not been found. Variations in productivity/fertility produce much smaller variations in benthos/plankton foraminiferal ratios than those observed in Core 532B-17. For example, off NW Africa the onset of upwelling influence produced an increase in benthos/plankton foraminiferal ratios from 9 to $17 \%$ in similar water depths (Diester-Haass, 1978). For these reasons, we conclude that lateral supply of benthos is not a significant factor in the benthonic to planktonic foraminifera ratio at this site.

The benthonic/planktonic foraminifera ratio (Fig.2f) parallels the curves of $\mathrm{CaCO}_{3}$ content and the variations in fragmentation of planktonic foraminifera. Light units have high $\mathrm{CaCO}_{3}$ content and low $\mathrm{CaCO}_{3}$ dissolution as documented by low fragmentation and low benthos/plankton foraminiferal ratios. Dark units, however, have lower $\mathrm{CaCO}_{3}$ contents and high $\mathrm{CaCO}_{3}$ dissolution revealed by higher fragmentation of planktonic foraminifera and very high benthos/plankton foraminiferal ratios.

The benthonic/planktonic foraminifera ratios vary from 10 up to $90 \%$. A ratio of about $1-10 \%$ is normal for the water depth of $1300 \mathrm{~m}$ (Diester-Haass, 1982; J.M. Bremner, pers. commun., 1985). $\mathrm{CaCO}_{3}$ dissolution is intense when ratios increase up to $90 \%$. In the Late Quaternary sequence of Hole 532, fragmentation is only $40-65 \%$ and the benthos/plankton foraminiferal ratios correspondingly increase only up to $50 \%$ (Diester-Haass, 1985).

We conclude that $\mathrm{CaCO}_{3}$ dissolution has a major influence on the lightdark layering and on the $\mathrm{CaCO}_{3}$ content. The dark layers are produced by strong dissolution; the light ones by lesser dissolution of $\mathrm{CaCO}_{3}$. This finding is contrary to the conclusions of Gardner et al. (1984), who believe that dissolution is not important and that dilution by terrigenous clay is the main reason for light-dark cycles in these Walvis Ridge sediments.

What is responsible for these strong variations in carbonate dissolution? In the deeper parts of the Atlantic Ocean, calcium-carbonate dissolution variations have been found in a glacial-interglacial periodicity and attributed to depth variations of the Antarctic Bottom Water (Gardner, 1975, Balsam, 1983) 
or to variations in the $\mathrm{CO}_{3}^{2-}$ ion concentrations (Broecker and Takahashi, 1978; Thunnell, 1982). In the shallow area (1300 $\mathrm{m}$ water depth) investigated here, these explanations are not applicable because it is outside of the influence of the AABW and far above the calcite compensation depth.

A possible factor involved in the strongly varying carbonate dissolution rate is the dissolved $\mathrm{CO}_{2}$ content of the bottom water and upper sediment layers. This is strongly influenced by input of organic matter and its subsequent oxidation. This $\mathrm{CO}_{2}$, produced by bacterial activity from organic matter, increases carbonate dissolution (Berger, 1970; Thunell, 1976; Swift and Wenkam, 1978). In the sediments of Core 532B-17, organic matter contents are rather high and provide a potential source of sea-bottom $\mathrm{CO}_{2}$.

\section{Varying production of calcium carbonate}

Production of calcareous microfossils may have varied to cause deposition of the light and dark units. If the light units represent periods with higher upwelling influence, the associated fertility increase in the surface water may have increased production of coccoliths and planktonic foraminifera. Investigations off NW Africa, however, have shown that an increase in fertility produces a rather small increase in the accumulation rate of planktonic foraminifera (Diester-Haass, 1976). Although benthonic foraminiferal accumulation rates are highly enhanced during increased upwelling, benthonic foraminifera normally form only a small proportion of total foraminifera tests in depths such as $1300 \mathrm{~m}$ (Diester-Haass, 1976) and thus are unlikely to be an important factor in the large increases in $\mathrm{CaCO}_{3}$ content in interglacial periods when the lighter units were deposited. On a broader scale, Einsele (1982) discounts the importance of $\mathrm{CaCO}_{3}$ production variations in causing chalk-marl cycles in sediments.

\section{Varying dilution of calcium carbonate by terrigenous matter and/or opal}

Changes in the proportions of insoluble terrigenous matter and biogenous opal might be an important factor for varying the $\mathrm{CaCO}_{3}$ concentrations. The composition of the coarse fraction (Fig.2d) shows larger radiolarian percentages in the carbonate-poor units. A more careful consideration reveals (see later) that this is an effect of dilution by planktonic foraminifera. Opal accumulation is actually higher during the warm periods when better $\mathrm{CaCO}_{3}$ preservation occurs than in the dark-colored, glacial intervals. As a result, diatoms are more abundant in the light units and somewhat dilute their high carbonate contents.

The amount of terrigenous matter correlates well with sediment color: higher amounts of terrigenous particles $>40 \mu \mathrm{m}$ are found in the dark units and lower values in the light units (Fig.4a). This can be due to varying dilution of terrigenous matter by dissolution of $\mathrm{CaCO}_{3}$ or to varying supply of terrigenous matter. During glacial intervals (dark units), the supply of terrigenous material is enhanced by factors of 2-6 relative to the interglacial units (Fig.4a and b), and so dilution of $\mathrm{CaCO}_{3}$ by continental debris evidently 
contributes to the light-dark cycles. Our quantitative data is only on the 40-63 $\mu \mathrm{m}$ sized terrigenous matter, yet we believe the assumption that an increase in supply of $40-63 \mu \mathrm{m}$ sized terrigenous matter is accompanied by an increase in $<40 \mu \mathrm{m}$ sized terrigenous fractions is justified.

\section{Marine fertility and productivity}

Changes in coastal marine fertility can be produced by variations in upwelling intensity and in river discharge. Enhanced productivity resulting from nutrient enrichment from either upwellings or rivers produces the same effect in underlying sediments: increases in concentrations of organic matter, biogenous opal, benthos, echinoderm spicules (Chamley and Diester-Haass, 1982), and perhaps fish debris (Diester-Haass, 1983a, b; Diester-Haass, 1985). A distinction between nutrient enrichment by rivers and by upwelling has been possible up to now only by means of sedimentological parameters: river discharge in subtropical/tropical regions is characterized by high $<2 \mu \mathrm{m}$ fraction contents and by abundant debris of land plants in the sediments (op. cit.; Rogers, 1973; Sarnthein, 1982). Our samples from Hole 532B contain neither plant debris nor marked increases in the $<2 \mu \mathrm{m}$ fraction. Furthermore, the clay-mineral composition is constant throughout Core 532B-17, with mineral assemblages typical of arid weathering conditions (see later). River discharge does not seem to have been an important factor involved in the productivity variations, and we can focus on changes in upwelling intensity to explain the fluctuations in organic matter and biogenous opal contents in these Plio-Pleistocene sediments.

The organic matter content is higher in dark units than in the light ones, and we calculated that during cold periods there is an additional supply of organic matter (Fig.3a, b, and Table 1). The biogenic opal content, formed by diatoms and radiolaria, is an important factor related to fertility in surface waters (Goll and Bjørklund, 1974; Maynard, 1976; Diester-Haass, 1978). It is higher in the light units deposited in interglacial periods than in the dark ones (Fig.4d, e, f). The radiolarian/diatom ratio is a measure of opal preservation, but also of opal production and thus fertility (Goll and Bjørklund, 1974). The higher the fertility in the surface waters, the higher the diatom production and the more opal is contributed to the sediment. This increase in opal supply enhances preservation of opal, especially that of diatoms, which are more easily dissolved than radiolaria. Thus radiolarian/diatom ratios decrease with increased productivity. Light units show smallest radiolarian/diatom ratios and thus record the highest productivity (Fig.3f).

Echinoderm spicules have been found to be sensitive indicators of increased food supply at the sea floor (Sarnthein, 1970; Chamley and Diester-Haass, 1982; Diester-Haass, 1985). The percentage of spicules in the total benthos shows higher values in the light than in the dark units and thus indicates higher fertility (Fig.3g).

We conclude that in the light units, which were deposited during intergla- 
cial periods, fertility in the surface water was higher than in the dark units, which were deposited during glacial periods. This finding seems to be a contradiction to the organic carbon content, which shows the opposite trend: higher amounts of organic matter in dark units than in light ones.

To explain this apparent contradiction, the local circulation of the surface ocean should be considered (Hart and Currie, 1960; Van Zinderen-Bakker, 1976; Martin, 1981; Hagen et al., 1981). During warm interglacial periods, the Benguela Current flows northward parallel to the coast of Namibia to about $23-20^{\circ} \mathrm{S}$. Strong coastal upwelling occurs over the inner shelf and at the shelf edge (Summerhayes, 1983). At $20^{\circ} \mathrm{S}$ the current turns westward (Fig.5A). From the north, tropical water moves southward to about $20^{\circ} \mathrm{S}$. At about $20^{\circ} \mathrm{S}$ (the latitude of Site 532), eddies of tropical water drifting towards the coast and eddies of upwelled water drifting to the sea are formed. The eddies of upwelled water drifting seaward contain opaline skeletons (Goll and Bjørklund, 1974; Schuette and Schrader, 1981; Hagen et al., 1981) as typical indicators of upwelling. Upwelling, centered on the shelf and shelf edge, is recorded in the sediments from Hole 532B because of westward transport by drifting eddies of upwelled water. This process explains the high opal content in the lightcolored interglacial intervals in Site 532, which do not indicate anything about upwelling intensity on the shelf, but are only a signal of the westward turning Benguela Current which carries opal from the upwelling area to the core site. Similar patterns of interglacial high opal content and lower glacial values has been found in oxygen isotope stages 1-6 of Hole 532 (Diester-Haass, 1985).

During glacial periods, the Benguela Current did not turn westward at $23-20^{\circ} \mathrm{S}$, but continued to flow close to the coast until about $17^{\circ} \mathrm{S}$ (Van Zinderen-Bakker, 1976; Fig.5B). Westward-drifting upwelled water masses did not occur at $20^{\circ} \mathrm{S}$, the area of Hole 532B, and biogenous opal deposition, consequently, was much lower in glacial times than during interglacial times.

In view of these changes in surface currents, how can the increased organic matter content in glacial intervals be explained? Two possibilities can be considered: (1) "shelf-to-basin transfer of organic matter" (Berger, 1970, 1982; Crowley, 1983); and (2) lowering of oxygen minimum zone.

In interglacial periods, sediments rich in organic matter are deposited on the broadened continental shelves of the world (Broecker, 1982). During glacial sea-level regressions, transfer of organic matter from the shelf to the continental slope accompanies erosion of the subaerially exposed sediments. Numerous examples of increased supply of organic matter during glacial periods to the continental slopes have been cited (Berger, 1970; Müller, 1975; Berger and Vincent, 1981).

A lowering of the oxygen minimum zone, which presently is at $400-800 \mathrm{~m}$ water depth off Namibia (Hagen et al., 1981; Summerhayes, 1983), will enhance preservation of organic matter because a lessened oxygen content slows bacterial decomposition of organic matter. If this possibility occurred, better carbonate preservation should be found than in interglacial periods because a 

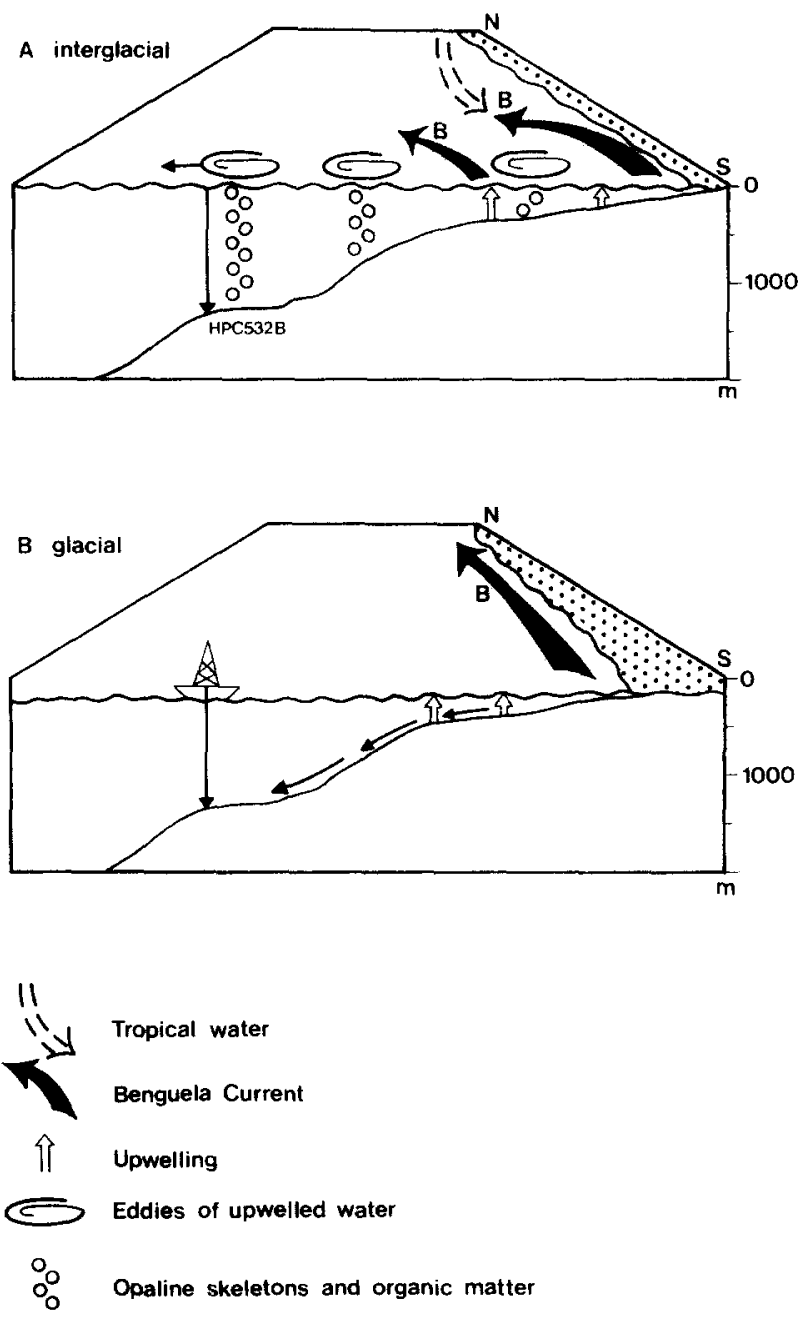

Fig.5. Schematic diagram showing hydrography in the area of Site 532 during deposition of light units (interglacial periods) and of dark units (glacial periods). A. Interglacial periods: eddies of upwelled water from the inner-shelf upwelling area are transported westward by the west-turning Benguela Current. These eddies contain opaline skeletons and organic matter. B. Glacial periods: Benguela Current flows parallel to the coast northward. No west-turning component, no eddies of upwelled water in the area of Site 532. Upwelling influence is concentrated on the near-coastal area. Sea level is lowered, thus bottom supply of organic matter from the outer shelf downslope is enhanced.

decrease in bacterial decomposition leads to diminished $\mathrm{CO}_{2}$ production and thus less carbonate dissolution. This hypothesis can be excluded because carbonate dissolution in glacial periods increases.

We conclude that increased lateral supply of organic matter by bottom currents explains higher organic matter contents in glacial intervals. This 
interpretation implies that the food supply at the sea floor was greater during glacial than during interglacial periods. Percentages of echinoderm spicules, however, are higher in interglacial periods when upwelling occurred at Site 532. No information on spicule dissolution is available. Our findings suggest that echinoderms, which have calcite skeletons with $2-4 \% \mathrm{Mg}$ (Milliman, 1974), are more readily dissolved in glacial intervals, when foraminifera and nannoplankton are also strongly dissolved, than in interglacial periods at this site. Hence, the value of spicules as fertility indicators is challenged as they appear to be subject to dissolution.

\section{Glacial-interglacial climatic changes}

These Walvis Terrace sediments provide an opportunity to consider possible changes of climatic conditions during the fluctuations from glacial to interglacial conditions indicated by $\delta^{18} \mathrm{O}$ values. A change in continental climate could account for the observed increase in terrigenous matter supply in the 40-63 $\mu \mathrm{m}$ fraction in the dark, glacial-period sediments. Alternatively, the increase could reflect stronger winds and enhanced eolian supply under generally unchanged climatic conditions on the continents.

Climatic variations on continents can be detected in continental slope sediments from grain-size variations of terrigenous matter, mineralogical composition, plant debris, and fluviatile diatoms (Rogers, 1973; Sarnthein, 1982; Diester-Haass, 1983a, b).

Site 532 lies off the Namib desert. Terrigenous matter may reach the core site from eolian transport or from fluvial transport from the African continent. Direct fluvial sediment supply from local rivers is improbable because landderived plant debris is absent and the $<2 \mu \mathrm{m}$ fraction is not abundant (Bremner, 1975; Diester-Haass, 1985). Furthermore, pollen analyses by Van Zinderen-Bakker (1984) indicate that arid conditions prevailed along the Namibian coast since late Miocene times, making river supply from this coast even less probable. Eolian supply is also not important (K. Heine, pers. commun., 1985), largely because prevailing winds of today do not blow seaward from the Namib in the region of $20^{\circ} \mathrm{S}$.

The Orange River, reaching the sea at about $28-29^{\circ} \mathrm{S}$, transports enormous quantities of river mud to the ocean which could be distributed northward by the Benguela Current. Although information is not available on the amount and direction of dispersal of Orange River muds in the sea, comparison of the clay-mineral composition of samples from the Namib desert and from Orange River muds (kindly provided by $\mathrm{K}$. Heine) with the clay-mineral spectrum from Site 532 shows that Site 532 and Orange River muds contain nearly the same clay-mineral spectrum, whereas Namib samples are quite different (Table 2). These results point to the possibility that most of the clay minerals present in Site 532 sediments originated from the Orange River and that eolian supply from the Namib was minor for the clay fraction but occurred mainly in the silt fraction during this period of time near the Plio-Pleistocene boundary. 
TABLE 2

Comparison of average clay-mineral assemblages in sediments from Site 532, the Orange River, and the Namib Desert and in atmospheric dust from the eastern South Atlantic

\begin{tabular}{|c|c|c|c|c|}
\hline Sample (latitude, age) & $\begin{array}{l}\text { Chlorite } \\
(\%)\end{array}$ & $\begin{array}{l}\text { Illite } \\
(\%)\end{array}$ & $\begin{array}{l}\text { Kaolinite } \\
(\%)\end{array}$ & $\begin{array}{l}\text { Montmorillonite } \\
(\%)\end{array}$ \\
\hline $\begin{array}{l}\text { Core 532B-17 } \\
\text { (19 } 44^{\prime} \mathrm{S}, \text { Plio-Pleistocene) }\end{array}$ & trace & $30 \cdots 45$ & 3.5 & 5265 \\
\hline $\begin{array}{l}\text { Helskloofhek, } \\
\text { Orange River (ca. } 29 \mathrm{~S} \text {, modern) } \\
\text { (samples of K. Heine) }\end{array}$ & & $30 \cdot 50$ & & $50 \cdot 70$ \\
\hline $\begin{array}{l}\text { Bullsport, Visrivier, } \\
\text { Sossug Vlei, Namib } \\
\text { (ca. } 24^{\prime} 30^{\prime} \text { S, modern) } \\
\text { (samples of K. Heine) }\end{array}$ & 1016 & $84-90$ & & \\
\hline $\begin{array}{l}\text { Profile E } 11 \\
\text { (15 } 21 \text { S, modern) } \\
\text { (Chester et al., 1972) }\end{array}$ & 17 & 40 & 26 & 17 \\
\hline $\begin{array}{l}\text { Profile E } 12 \\
\text { (21-26 S, modern) } \\
\text { (Chester et al., 1972) }\end{array}$ & 25 & 50 & 25 & $\cdots$ \\
\hline
\end{tabular}

The observation of an increase in terrigenous silt-sized matter during glacial periods in Site 532 sediments (Fig.4) can be explained by increased wind velocities and thus increased local supply from the Namib desert. As shown in Fig.6, most of the increase in the silt fraction is due to increases in quartz content of the sediment. An additional source of insoluble material might be erosion of the subaerially exposed shelf during the deposition of the dark, glacial-period layers.

The clay-mineral composition of the $<2 \mu \mathrm{m}$ fraction is uniform. No significant changes can be observed throughout the sediment column studied, nor can the small compositional changes (Fig.4d) be related to dark-light cycles. We conclude that neither the source area nor the climatic conditions of this area changed during the corresponding time intervals.

We infer that all clay minerals are detrital and hence are valid indicators of the continental climates of their source regions. Our inference is based upon the observation that detrital quartz concentrations vary with both illite and montmorillonite (Fig.6) and is supported by two other observations. First, the illite peak is sharp, indicating good crystallinity and making diagenetic formation from montmorillonite unlikely. Second, the absence of volcanic material in these sediments rules out a diagenetic origin of the montmorillonite.

The clay minerals in Core 532B-17 have the same composition as the modern Orange River mud. We conclude that in this Plio-Pleistocene time the Orange River was the major source of clays in Site 532 and that the climate in the area of origin remained unchanged during glacial and interglacial periods and was similar to the present, dry one. 
(a)

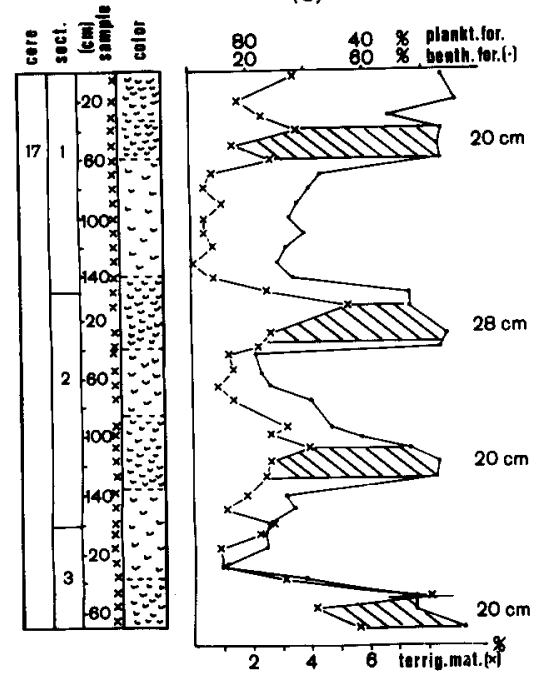

(b)

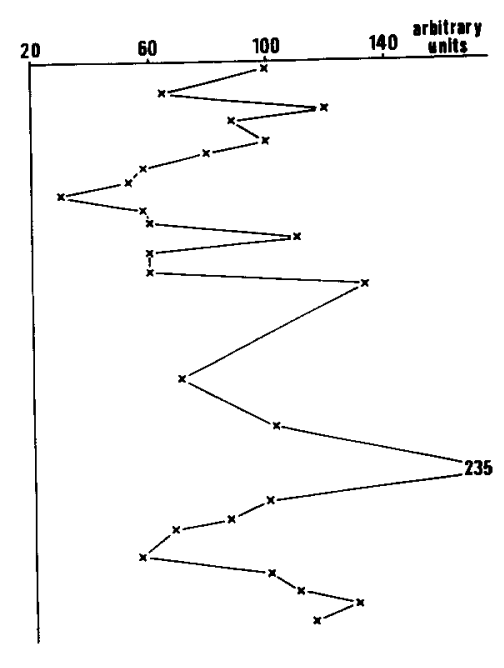

Fig.6. (a) Benthos/plankton foraminiferal ratios (as in Fig.2f) and amount of terrigenous matter in percent of $40-63 \mu \mathrm{m}$ fraction (as in Fig.4a). Lag in maxima of both parameters (shaded area). (b) Weights of the 101 quartz peak from bulk sediment samples from Core 532B-17.

The only difference between Site 532 sediments and Orange River muds is the presence of small contributions of kaolinite in Site 532 samples. Kaolinite indicates tropical weathering. The very low kaolinite content suggests that there is no major influence from the Kunene shelf to the north (Fig.1), inasmuch as Bremner (1975) observed an increase in kaolinite in surface samples off the Kunene River and explained it by the supply of clay minerals from tropical areas.

To test further the possible importance of eolian input of continental materials, we compared the clay-mineral composition of Site 532 sediments to that of atmospheric dust collected off SW Africa (Chester et al., 1972) (Table 2). The atmospheric dusts differ from the sediments by having rather high kaolinite and chlorite contents, whereas montmorillonite and illite are the main components of the Site 532 sediments. The difference can be explained by our assumptions that the clay minerals of Site 532 originate mainly from the Orange River and that eolian sources are of minor importance.

When comparing the variation over time in $40-63 \mu \mathrm{m}$ sized terrigenous matter, and in quartz and the variation of $\mathrm{CaCO}_{3}$ dissolution, we find a lag of about $20 \mathrm{~cm}$ between maxima of these parameters (Fig.6). This implies that an event occurring in the sea - the maximum in carbonate dissolution - and an event, occurring in the atmosphere above the continent - the maximum in terrigenous matter supply — are displaced by about 4000 years, assuming accumulation rates of $5 \mathrm{~cm} 1000 \mathrm{yrs}^{-1}$ (Dean et al., 1984).

We suggest the following sequence: during the transition from an interglacial to a glacial period, sea level is lowered relatively rapidly. An increase in organic matter quickly results, and bacterial decomposition of the organic 
matter produces a spike in carbonate dissolution. Maxima in dissolution and in organic matter are at the same sediment depth. During this dissolution spike, terrigenous sediment supply is still low, close to interglacial conditions. The ratio of measured versus calculated terrigenous material amounts is also low (Fig.4b). After about 4000 years past the dissolution spike, wind strength has reached its maximum and enhances the supply of $40-63 \mu \mathrm{m}$ sized terrigenous matter. The tm/tc ratio is highest (Fig.4b) when carbonate dissolution decreases. During the transition from the glacial interval to the following interglacial interval, sea-level rise and wind strength decrease are simultaneous, and minima in calcium-carbonate dissolution and in terrigenous matter supply occur in the same sediment interval.

\section{CONCLUSIONS}

(1) The primary cause of the light dark variations in the color of PlioPleistocene sediment deposited at Site 532 on the Walvis Ridge is from variations in preservation of biogenic carbonates. Light cycles correspond to interglacial periods of better preservation; dark cycles occur during glacial times of greater carbonate dissolution.

(2) Carbonate dissolution at this location has been influenced largely by the supply of oxidizable organic matter to the sea bottom. Dark-colored sediment units contain evidence of enhanced influx or organic matter, probably through downslope transfer from shallower locations during periods of glacially lowered sea level.

(3) Marine productivity over this part of the Walvis Ridge has been greater during interglacial times than during glacial periods, reflecting shifts in the location of the main core of the Benguela Current and associated upwelling eddies with these climatic changes.

(4) The clay-sized terrigenous matter in Site 532 sediments originated mainly from the Orange River and was transported by the Benguela Current northward to the Walvis Ridge. The clay-mineral composition remained constant in glacial and interglacial intervals. The silt-sized terrigenous matter is assumed to originate from local sources in the Namib by wind. This eolian supply increased during glacial periods as an additional factor contributing to lowering the carbonate concentrations of sediments.

\section{ACKNOWLEDGEMENTS}

We thank Nicholas Shackleton for providing the oxygen isotope data and G. Frion for performing clay-mineral analyses. An early version of this paper was reviewed by Constance Sancetta and Detmar Schnitker, both of whom provided valuable suggestions for improvement. K. Heine of the University of Regensburg graciously shared with us his samples from the Namib Desert and the Orange River; we thank him for this and for his valuable discussions about mineral origins. Laboratory assistance was provided by Martina Killinger and 
Nicola Klupsch, and graphics were done by Marianne Mitlehner, Sebastian Lenz, and Matthias Werner.

We thank the International Program of Ocean Drilling of the Deep Sea Drilling Project for providing the samples analyzed in this study. Funding for this study was provided by the Deutsche Forschungsgemeinschaft (Grant No. Ro 278/12-4), the U.S. National Science Foundation (Grant No. OCE 8214605), the American Philosophical Society, and the Rackham International Partnerships Program of The University of Michigan. P.A.M. is especially grateful for the opportunity to have been on DSDP Leg 75.

\section{REFERENCES}

Balsam, W.L., 1983. Carbonate dissolution on the Muir Seamount (western North Atlantic): interglacial/glacial changes. J. Sediment. Petrol., 53(3): 719-731.

Berger, W.H., 1970. Planktonic foraminifera: selective solution and the lysocline. Mar. Geol., 8: 111-138.

Berger, W.H., 1971. Sedimentation of planktonic foraminifera. Mar. Geol., 11: 325-358.

Berger, W.H., 1982. Deep-sea stratigraphy: Cenozoic climate steps and the search for chemoclimatic feedback. In: G. Einsele and A. Seilacher (Editors),, Cyclic and Event Stratification. Springer, Berlin, pp.121-157.

Berger, W.H. and Vincent, E., 1981. Chemostratigraphy and biostratigraphic correlation: exercises in systematic stratigraphy. Oceanol. Acta, Proc. 26th Int. Geol. Congress, Geology of Oceans, pp.115-127.

Berger, W.H., Bonneau, M.C. and Parker, F.L., 1982. Foraminifera on the deep-sea floor, lysocline and dissolution rate. Oceanol. Acta, 5(2): 249-258.

Biscaye, P.E., 1964. Distinction between kaolinite and chlorite in recent sediments by X-ray diffraction. Am. Mineral., 49: 1281-1289.

Bremner, J.M., 1975. Physiography of the Kunene-Walvis shelf and adjacent drainage area. Tech. Rep., No. 7, Geol. Dept. Univ. of Cape Town, pp.59-67.

Broecker, W.S., 1982. Glacial to interglacial changes in ocean chemistry. Progr. Oceanogr., II: 151-197.

Broecker, W.S. and Takahashi, T., 1978. The relationship between lysocline depth and in situ carbonate ion concentration. Deep-Sea Res., 25: 65-95.

Chamley, H. and Diester-Haass, L., 1982. Effets du déplacement de l'embouchure du fleuve Sénégal, au Quaternaire supérieur, sur la sédimentation de la marge ouest-africaine. C.R. Acad. Sci., II, 295: 673-678.

Chamley, H., Giroud d'Argoud, G. and Robert, C., 1977. Genèse des smectites messiniennes de Sicile. Implications Paléoclimatiques Géol. Méditerr., IV/4: 371-378.

Chester, R., Elderfield, H., Griffin, J.J., Johnson, L.R. and Padgham, R.C., 1972. Eolian dust along the Eastern margins of the Atlantic Ocean. Mar. Geol., 13: 91-105.

Crowley, T.J., 1983. Calcium carbonate preservation patterns in the Central North Atlantic during the last 150,000 years. Mar. Geol., 51: 1-14.

Dean, E.D., Gardner, J.V. and Cepek, P., 1981. Tertiary carbonate dissolution cycles on the Sierra Leone Rise, Eastern equatorial Atlantic Ocean. Mar. Geol., 39: 81-101.

Dean, W.E., Hay, W.W. and Sibuet, J.-C., 1984. Geologic evolution, sedimentation, and paleoenvironments of the Angola Basin and adjacent Walvis Ridge: Synthesis of results of Deep Sea Drilling Project Leg 75. In: W.W. Hay, J.-C. Sibuet et al., Initial Reports of the Deep Sea Drilling Project, vol. 75. U.S. Govt. Printing Office, Washington, D.C., pp.509-544.

Diester-Haass, L., 1976. Quaternary accumulation rates of biogenous and terrigenous components on the East Atlantic continental slope off NW Africa. Mar. Geol., 21: 1-24. 
Diester-Haass, L., 1977. Radiolarian/planktonic foraminiferal ratios in a coastal upwelling region. J. Foraminifer. Res., 7(1): 26-33

Diester-Haass, L., 1978. Sediments as indicators of upwelling. In: R. Boje and M. Tomczak (Editors), Upwelling Ecosystems. Springer, Berlin, pp.261 281.

Diester-Haass, L., 1982. Indicators of water depth in bottom sediments of the continental margin off West Africa. Mar. Geol., 49: 311 - 326.

Diester-Haass, L., 1983a. Differentiation of high oceanic fertility in marine sediments caused by coastal upwelling and/or river discharge off Northwest Africa during the Late Quaternary. In: J. Theide and E. Suess (Editors), Coastal Upwelling. Its Sediment Record. (NATO conf. Ser., IV. 10b) Plenum, New York, N.Y., pp.399 419.

Diester-Haass, L., 1983b. Late Quaternary sedimentation processes on the West African continental margin and climatic history of West Africa (12 18 N). "Meteor" Forschungsergeb.. Reihe C. 37: 4784 .

Diester-Haass, L., 1985. Late Quaternary sedimentation on the eastern Walvis Ridge, SE Atlantic (HPC 532, IPOD Leg 75) and neighbored piston cores. Mar. Geol., 65: 145-189.

Diester-Haass, L., Schrader, H.-J. and Thiede, J., 1973. Sedimentological and paleoclimatological investigations of two pelagic ooze cores off Cape Barbas, NW Africa. "Meteor" Forschungsergeb., Reihe C, 16: 1966 .

Einsele, G., 1982. Limestone marl cycles (periodites): diagnosis, significance, causes - a review. In: G. Einsele and A. Seilacher (Editors), Cyclic and Event. Stratification. Springer, Berlin, pp.8 53.

Gardner, J.V., 1975. Late Pleistocene carbonate dissolution cycles in the Eastern equatorial Atlantic. In: Dissolution of Deep-Sea Carbonates. Cushman Found. Foraminifer. Res., Spec. Publ., 13: 129141.

Gardner, J.V., Dean, W.E. and Wilson, C., 1984. Carbonate and organic-carbon cycles and the history of upwelling at DSDP Site 532, Walvis Ridge, South Atlantic Ocean. In: W.W. Hay, J.C. Sibuet et al., Initial Reports of the Deep Sea Drilling Project, vol. 75. U.S. Govt. Printing Office, Washington, D.C., pp.905-921.

Goll, R.M. and Bjørklund, K.R., 1974. Radiolaria in surface sediments of the South Atlantic. Micropaleontology, 20: 38-75.

Hagen, E., Schemainda, R., Michelsen, N., Postel, L., Schulz, S. and Below, M., 1981. Zur kustensenkrechten Struktur des Kaltwasserauftriebes vor der Küste Namibias. Geodat., Geophys. Veröff., IV, 36: 99 pp.

Hart, T.J. and Currie, R.T., 1960. The Benguela Current. "Discovery" Rep., 31: 123298.

Hay, W.W., Sibuet, J.C. et al., 1984. Initial Reports of the Deep Sea Drilling Project, vol. 75. U.S. Govt. Printing Office, Washington, D.C., 1303 pp.

Martin, R.A., 1981. Benthonic foraminifera from the Orange Luderitz shelf, Southern African continental margin. Bull. Mar. Geosci. Unit, No. II, Dept. of Geol., Univ. of Cape Town, 82 pp.

Maynard, N., 1976. Relationship between diatoms in surface sediments of the Atlantic Ocean and the biological and physical oceanography of overlying waters. Paleobiology, 2: 99-121.

Milliman, J.D., 1974. Marine Carbonates. Springer, Berlin, 375 pp.

Müller, P.J., 1975. Diagenese stickstoffhaltiger organischer Substanzen in oxischen und anoxischen marinen Sedimenten. "Meteor" Forschungsergeb., Reihe C, 22: 1-60.

Rogers, J., 1973. Texture, composition and depositional history of unconsolidated sediments from the Orange-Luderitz shelf, and their relationship with Namib desert sands. Tech. Rep. No. 5, Joint Geol. Survey, Univ. of Cape Town, Mar. Geol. Progr., pp.67-88.

Sancetta, C., 1984. Diatoms from Leg 75, Deep Sea Drilling Project. In: W.W. Hay, J.-C. Sibuet et al., Initial Reports of the Deep Sea Drilling Project, vol. 75. U.S. Govt. Printing Office, Washington, D.C., pp.755-759.

Sarnthein, M., 1970. Sedimentologische Merkmale für die Untergrenze der Wellenwirkung im Persischen Golf. Geol. Rundsch., 59: 649 666.

Sarnthein, M., 1982. Zur Fluktuation der subtropischen Wustengurtel seit dem letzten Hochglazial vor 18.000 Jahren: Klimahinweise und -modelle aus Tiefseesedimenten. Geomethodica, Veröff. 7, $\mathrm{BGC}, 7: 125-161$. 
Schuette, G. and Schrader, H.-J., 1981. Diatom taphocoenoses in the coastal upwelling area off South West Africa. Mar. Micropaleontol., 6: 131-155.

Siesser, W.G., 1980. Late Miocene origin of the Benguela Upwelling System off northern Namibia. Science, 208: 283-285.

Summerhayes, C.P., 1983. Sedimentation of organic matter in upwelling regimes. In: J. Thiede and E. Suess (Editors), Coastal Upwelling. Its Sediment Record. (NATO Conf. Ser., IV, 10b) Plenum, New York, N.Y., pp.29-72.

Swift, S.A. and Wenkam, C., 1978. Holocene accumulation rates of calcite in the Panama basin: lateral and vertical variation in calcite dissolution. Mar. Geol., 27: 67-77.

Thiede, J., Suess, E. and Müller, P.J., 1982. Late Quaternary fluxes of major sediment components to the sea-floor at the Northwest African continental slope. In: U. von Rad, K. Hinz, M. Sarnthein and E. Seibold (Editors), Geology of the Northwest African Continental Margin. Springer, Berlin, pp.605-631.

Thunell, R.C., 1976. Calcium carbonate dissolution history in Late Quaternary deep-sea sediments, Western Gulf of Mexico. Quat. Res., 6: 281-297.

Thunell, R.C., 1982. Carbonate dissolution and abyssal hydrography in the Atlantic Ocean. Mar. Geol., 47: 165-180.

Van Zinderen-Bakker, E.M., 1976. The evolution of Late Quaternary paleoclimates of Southern Africa. (Paleoecology of Africa, vol. IX) Balkema, Cape Town, pp.160-202.

Van Zinderen-Bakker, E.M., 1984. Palynological evidence for late Cenozoic arid conditions along the Namibia coast from Holes 532 and 530A, Leg 75, Deep Sea Drilling Project. In: W.W. Hay, J.C. Sibuet et al., Initial Reports of the Deep Sea Drilling Project, Vol. 75. U.S. Govt. Printing Office, Washington, D.C., pp.763-768. 